\title{
Hypogammaglobulinemia in a family with Crohn's disease
}

\author{
ROBERT ENNS MD, GUIDO VAN ROSENDAAL MD
}

\begin{abstract}
R ENNS, G VAN RosendaAl. Hypogammaglobulinemia in a family with Crohn's disease. Can J Gastroenterol 1996;10(5): 304-306. A 55-year-old woman presented with steroid refractory Crohn's disease. In anticipation of surgical therapy, a protein electrophoresis was done and demonstrated low serum immunoglobulins. Immunoglobulin analysis showed low levels of serum immunoglobulin $\mathrm{G}$, which persisted following surgical therapy despite a clinical remission. A diagnosis of combined variable hypogammaglobulinemia was made and her family was screened for a similar disorder. Four of the six family members known to have Crohn's disease were discovered to have low serum immunoglobulins. The presented patient was the index case in a family who has both hypogammaglobulinemia and Crohn's disease. Furthermore, the two disorders in this family appear to be closely linked. Future study of the association between these two disorders may enable a more clear definition of Crohn's disease pathogenesis.
\end{abstract}

Key Words: B lymphocytes, Crohn's disease, Hypogammaglobulinemia, T lymphocytes

\section{Hypoglammaglobulinémie chez les patients atteints de maladie de Crohn}

RÉSUMÉ : Il s'agit du cas d'une femme de 55 ans dont la maladie de Crohn est réfractaire aux corticostérö̈des. En vue d'un traitement chirurgical, une électrophorèse des protéines a été effectuée et a révélé un taux faible d'immunoglobulines sériques. L'analyse des immunoglobulines a révélé de faibles taux d'immunoglobulines $G$ sériques persistant après le traitement chirurgical, malgré une rémission clinique. Un diagnostic d'hypogammaglobulinémie variable combinée a été rendu et on a soumis sa famille à un dépistage de cette maladie. Chez quatre des six membres de sa famille ayant une maladie de Crohn avérée, on a découvert de faibles taux d'immunoglobulines sériques. La patiente a donc été le propositus d'une famille atteinte et d'hypogammaglobulinémie et de maladie de Crohn. De plus, dans cette famille, les deux maladies semblent intimement liées. La poursuite de la recherche sur une association entre ces deux maladies pourrait amener une définition plus claire de la pathogenèse de la maladie de Crohn.
Qrum immunoglobulins in most Crohn's disease patients $\checkmark$ are normal; however, there are occasional reports of Crohn's patients with hypogammaglobulinemia (1).

Low immunoglobulin levels are usually transient, and after appropriate therapy for the disease they increase. We report a case of hypogammaglobulinemia associated with Crohn's disease that did not resolve with appropriate therapy. Furthermore, when her family was screened, there was a strong correlation between family members with Crohn's disease and hypogammaglobulinemia.

\section{CASE PRESENTATION}

A 55-year-old female experienced an exacerbation of Crohn's disease, which was refractory to steroids. Ten years previously the diagnosis was made when recurrent episodes of colicky abdominal pain associated with nausea and vomiting necessitated hospital admission. Barium follow-through examination demonstrated narrowing of the terminal ileum, and she was put on a tapering steroid regimen. Over the next 10 years, biannual exacerbations in her disease were managed with short courses of prednisone and 5-aminosalicylic acid (5-ASA).

Over the year before the reported admission, the patient's symptoms became increasingly severe and she required a maintenance dose of prednisone $20 \mathrm{mg} /$ day. Despite the addition of metronidazole, nausea, vomiting and right lower quadrant pain persisted, resulting in a 2 to $3 \mathrm{~kg}$ weight loss. She had no extra-intestinal manifestations of Crohn's disease. Medical history included appendectomy, hysterectomy and rheumatic fever. Physical examination was normal except for right lower quadrant tenderness. Family history was significant in that she had six first-degree relatives with Crohn's disease.

Repeat barium study demonstrated a narrowed segment in

University of Calgary, Calgary, Alberta

Correspondence: Dr Robert Enns, 319 Sceptre Court, Calgary, Alberta T3L 1Y3. Telephone 403-547-3180, fax 403-670-2400, e-mail raenns@acs.ucalgary.ca 
the terminal ileum. Due to impending surgery, preoperative blood work, including a protein electrophoresis, was done. Because the protein electrophoresis demonstrated low gamma globulins $(3.0 \mathrm{~g} / \mathrm{L})$, immunoglobulin levels were analyzed. Serum immunoglobulins IgA and IgM were normal, but the IgG level was $4.49 \mathrm{~g} / \mathrm{L}$ (normal 6.39 to 13.49). She subsequently had an ileal resection of histologically proven Crohn's disease. Repeat IgG after the surgical resection was $3.61 \mathrm{~g} / \mathrm{L}$. Low levels of IgG persisted on repeat measurements over the next two years.

Abdominal symptoms resolved and 5-ASA maintenance therapy was initiated. Two years later she required admission for atypical pneumonia, and pulmonary function testing demonstrated findings consistent with chronic obstructive lung disease. Testing revealed that serum immunoglobulins were again low.

A diagnosis of hypogammaglobulinemia was made, and family screening was done (Figure 1). Four of the six family members with Crohn's disease had low serum immunoglobulins. Of these four, three had low IgG and one had low IgM. Only two family members without Crohn's disease were available to have serum immunoglobulins measured and these results were normal. The results demonstrate that the case outlined above was the index case in a family who appear to have coexistent Crohn's disease and hypogammaglobulinemia (Table 1).

\section{DISCUSSION}

Gastrointestinal disturbances such as Crohn's disease have been known to occur in patients with immunedeficient states (2). Some researchers have preferred to call these lesions 'regional enteropathy-like' states to denote their similarity to Crohn's disease (1). Others have simply called the lesions Crohn's disease and felt that it was associated with hypogammaglobulinemia (3). Despite normal levels of B lymphocytes, patients with hypogammaglobulinemia still have low immunoglobulin levels (4). One explanation is that there is intrinsic abnormality in the $\mathrm{B}$ lymphocyte function, which results in low immunoglobulin production. A second theory argues that there is stimulatory dysfunction, so B lymphocytes are not encouraged to produce appropriate levels of immunoglobulins; this theory is supported by several studies that demonstrated that when B cells from affected individuals are isolated and stimulated with specific cytokines, they produce appropriate levels of immunoglobulins. When $\mathrm{T}$ cells from affected patients are added to the matrix, immunoglobulin production decreases. Therefore, it appears that the defect in hypogammaglobulinemia may rest in abnormal $\mathrm{T}$ cell suppressor activity (4-9).

Only occasional individual reports of hypogammaglobulinemia associated with Crohn's disease have been published $(5,8)$. This case is unique in that our index patient had six first-degree relatives with Crohn's disease, four of whom had low levels of immunoglobulins. Three of these four had low serum IgG, and one had low serum IgM and borderline low IgA. These findings are similar to common variable hypo-

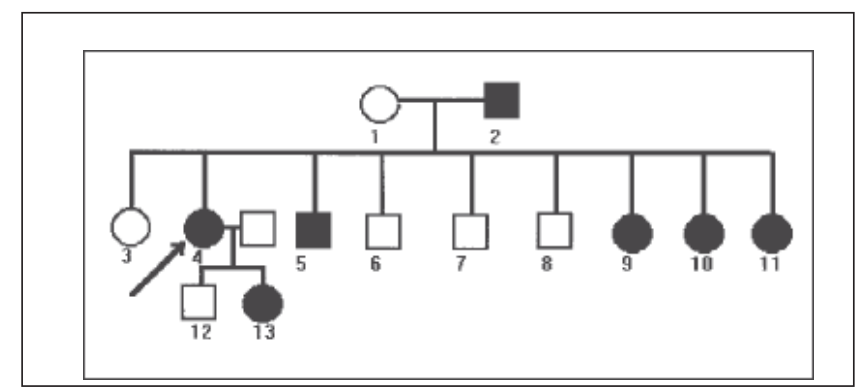

Figure 1) Pedigree of family with Crohn's disease. Arrow indicates index case. Numbers identify individuals for Table 1. 口Male; Affected male; OFemale; Affected female

TABLE 1

Results of screening family members of the index case

\begin{tabular}{cccc}
$\begin{array}{l}\text { Family } \\
\text { member }\end{array}$ & $\begin{array}{c}\text { IgA (g/L) } \\
\text { (normal 0.9-4.56) }\end{array}$ & $\begin{array}{c}\text { IgM (g/L) } \\
\text { (normal 0.69-2.16) }\end{array}$ & $\begin{array}{c}\text { IgG (g/L) } \\
\text { (normal 8.0-18) }\end{array}$ \\
\hline 2 & 1.03 & 0.56 & 11.8 \\
4 & 0.90 & 0.97 & 4.49 \\
5 & 2.73 & 1.37 & 9.2 \\
7 & 5.28 & 0.77 & 12.8 \\
8 & 1.90 & 1.01 & 9.1 \\
9 & 2.78 & 2.07 & 4.83 \\
10 & 3.29 & 0.87 & 8.4 \\
11 & 1.95 & 0.92 & 6.00 \\
13 & 1.80 & 1.18 & 7.6 \\
\hline
\end{tabular}

Numbers identify individuals for Figure 1. Ig Immunoglobulin

gammaglobulinemia, in which it is common to have low $\operatorname{IgM}, \operatorname{IgA}$ and $\operatorname{IgG}$, especially in siblings. Furthermore, our index case developed chronic obstructive lung disease, common in patients with hypogammaglobulinemia. In some reported cases of hypogammaglobulinemia in Crohn's disease, serum immunoglobulins returned to normal when the patient had the active disease treated. This did not occur in our index case; she had persistently low serum immunoglobulins after surgical correction and appropriate medical therapy.

\section{CONCLUSIONS}

The presented index case led us to evaluate further her family, and four other members were subsequently shown to have Crohn's disease and hypogammaglobulinemia. Serum immunoglobulins measured in the only two available family members without Crohn's disease were normal. It appears that in this family, Crohn's disease and hypogammaglobulinemia are closely linked. This finding deserves further study because its elucidation may help to define the pathogenesis of Crohn's disease more clearly.

ACKNOWLEDGEMENTS: This paper was a winning entry in the Inflammatory Bowel Disease Resident Case Study Competition, supported by an educational grant from Astra Pharma Inc.

\section{REFERENCES}

1. Abramowsky CR, Sorensen RU. Regional enteritis-like enteropathy in a patient with agammaglobulinemia: Histologic and immunocytologic studies. Hum Pathol 1988;19:483-6. 


\section{Enns and Van Rosendaal}

2. Marshak RH, Lindner AE, Maklansky D. Immunoglobulin disorders and the small bowel. Radiol Clin North Am 1976;14:477-91.

3. Rosen FS, Cooper MD, Wedgwood RJP. The primary immunodeficiencies. N Engl J Med 1995;333:431-40.

4. Saxon AS, Sidell N, Zhong K, et al. B cells from subjects can be driven to Ig production in response to CD40 stimulation. Cell Immunol 1992;144:169-81.

5. Elson CO, James SP, Graeff AS, Berendson RA, Strober W. Hypogammaglobulinemia due to abnormal suppressor T-cell activity in Crohn's disease. Gastroenterology 1984;87:569-76.
6. Nonoyama S, Farrington M, Isida H, Howard M, Ochs HD. Activated $\mathrm{B}$ cell from patients with common variable immunodeficiency proliferate and synthesize immunoglobulin. J Clin Invest 1933;92:1282-7.

7. Cooper MD, Lawton MD. Circulating B-cells in patients with immunodeficiency. Am J Pathol 1972;69:513-28.

8. Saxon A, Stevens RH, Ashman RF, Parker NH. Dual immune defects in nongranulomatous ulcerative jejunoiletis with hypogammaglobulinemia. Clin Immunol Immumopathol 1977;8:272-9.

9. Foe WF. Immunodeficiency and the GI tract. Clin Gastroenterol $1983 ; 12: 839-53$ 


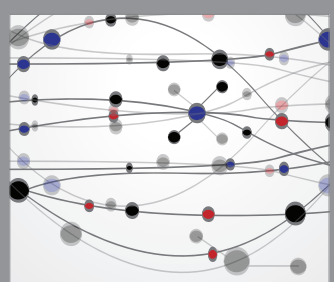

The Scientific World Journal
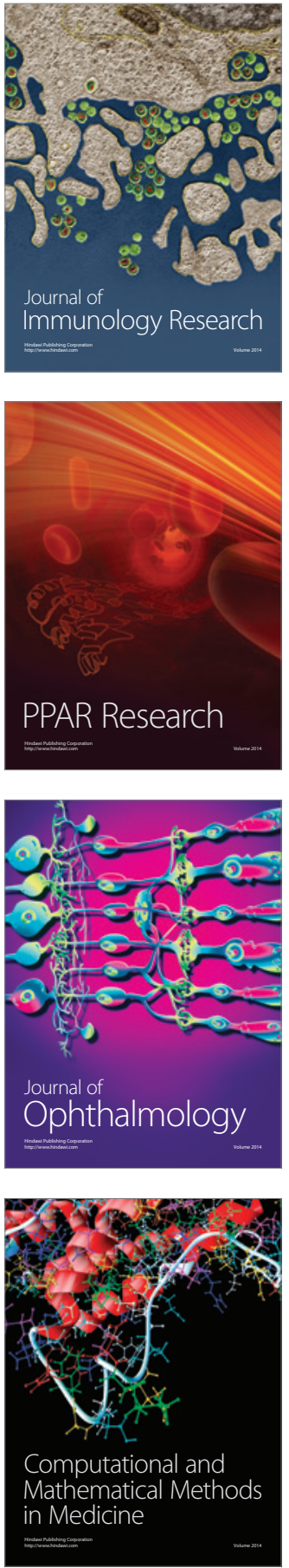

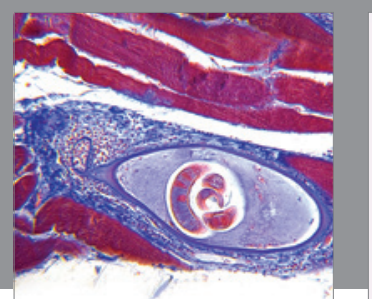

Gastroenterology Research and Practice

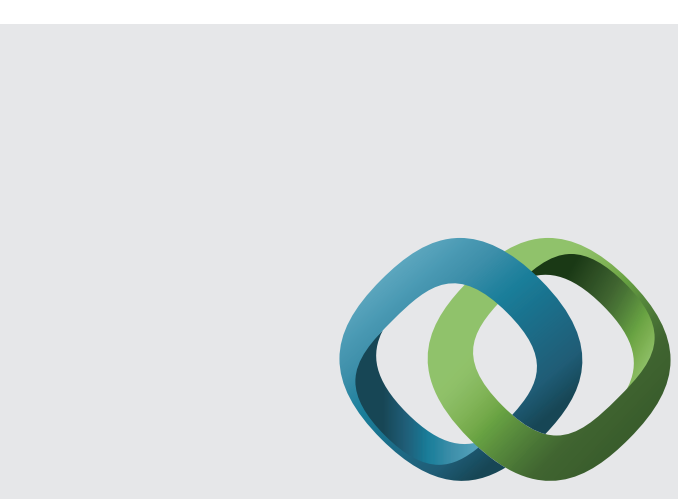

\section{Hindawi}

Submit your manuscripts at

http://www.hindawi.com
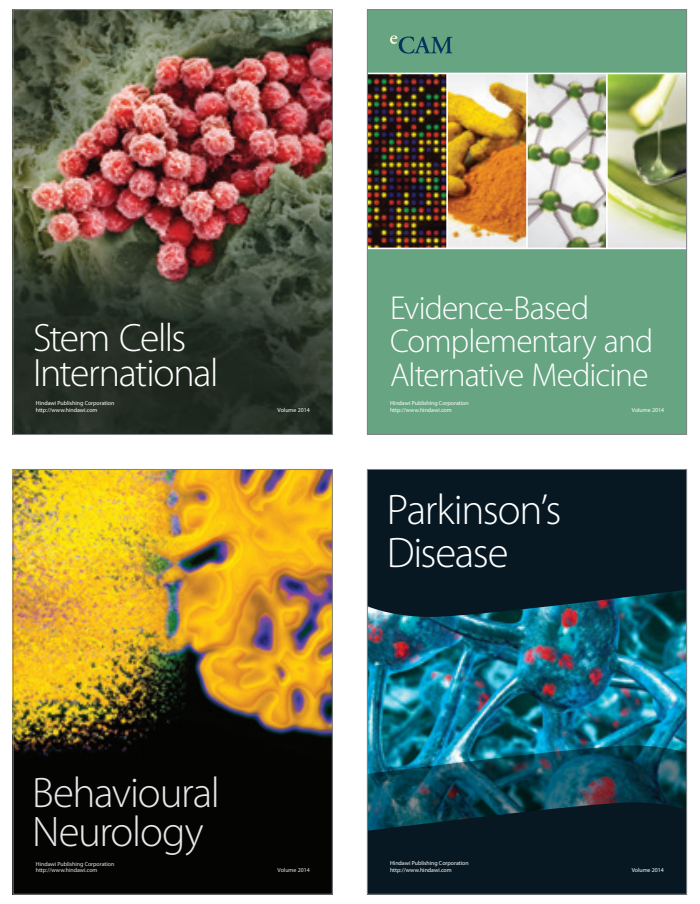
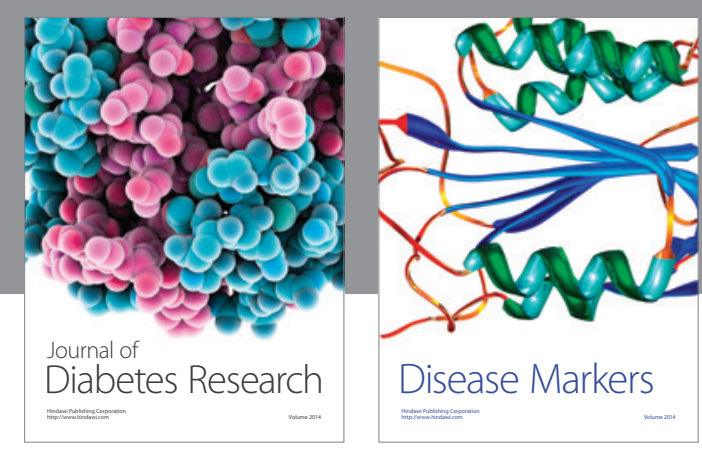

Disease Markers
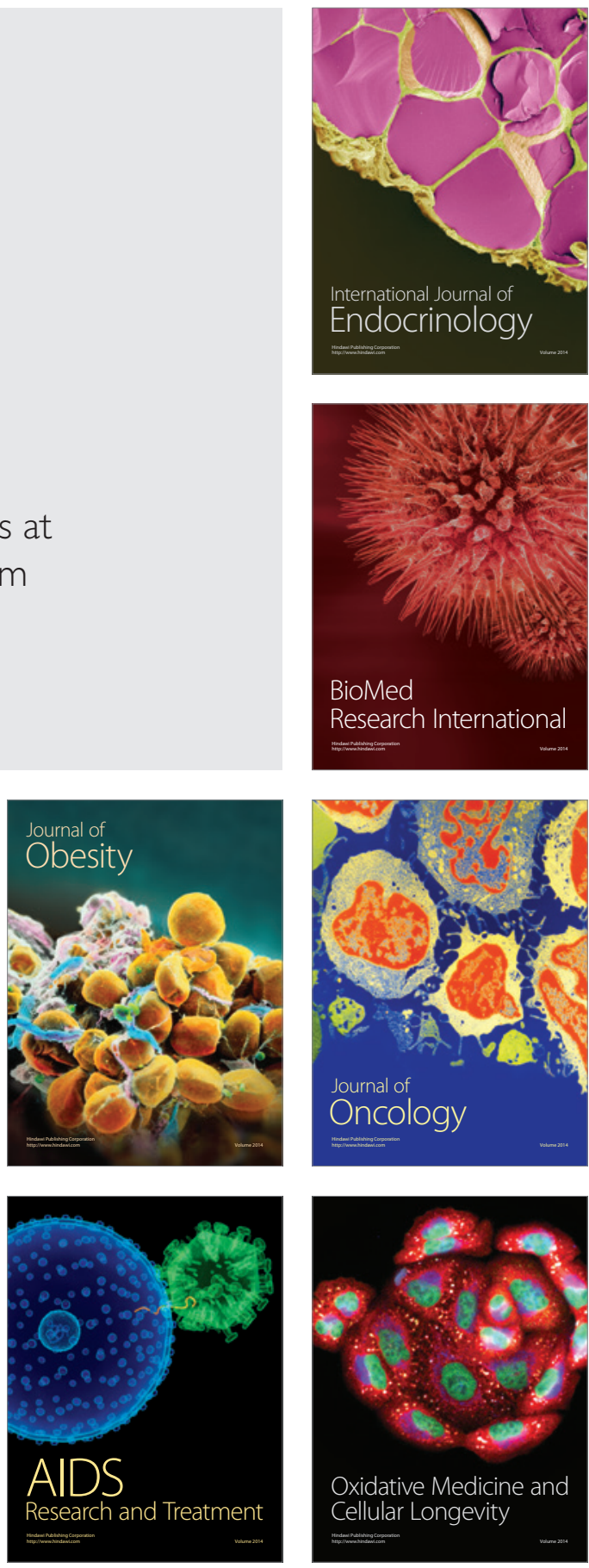